Lobtaritiats

\title{
Tracking residual organochlorine pesticides (OCPs) in green, herbal, and black tea leaves and infusions of commercially available tea products marketed in Poland
}

\section{Agata Witczak, Hassan Abdel-Gawad, Michal Zalesak \& Anna Pohoryło}

To cite this article: Agata Witczak, Hassan Abdel-Gawad, Michal Zalesak \& Anna Pohoryło (2017): Tracking residual organochlorine pesticides (OCPs) in green, herbal, and black tea leaves and infusions of commercially available tea products marketed in Poland, Food Additives \& Contaminants: Part A, DOI: 10.1080/19440049.2017.1411614

To link to this article: https://doi.org/10.1080/19440049.2017.1411614

Accepted author version posted online: 06

Dec 2017.

Submit your article to this journal $\widetilde{ }$

View related articles $\nearrow$

View Crossmark data $₫$ 
Publisher: Taylor \& Francis \& Informa UK Limited, trading as Taylor \& Francis

Journal: Food Additives \& Contaminants: Part A

DOI: $10.1080 / 19440049.2017 .1411614$

Tracking residual organochlorine pesticides (OCPs) in green, herbal, and black tea leaves and infusions of commercially available tea products marketed in Poland

Agata Witczak $^{\mathrm{a} *}$, Hassan Abdel-Gawad ${ }^{\mathrm{b}}$, Michal Zalesak ${ }^{\mathrm{c}}$ and Anna Pohoryło ${ }^{\mathrm{a}}$

${ }^{a}$ Department of Toxicology, West Pomeranian University of Technology, Szczecin, Poland; Papieża Pawta VI Str 3, 71-459 Szczecin

${ }^{b}$ Applied Organic Chemistry Department, Chemical Industries Research Division, National Research Centre Scopus Affiliation ID 60014618, 33 EL Buhouth St., Dokki, Giza, Egypt; ${ }^{c}$ Department of Environmental Protection Engineering, Tomas Bata University in Zlin, Vavreckova 275, 760 01, Zlin, Czech Republic

*Corresponding author. E-mail:agata.witczak@zut.edu.pl

\begin{abstract}
The content of residual organochlorine pesticides (OCPs) was examined in green, herbal, and black tea leaves as well as in their infusions prepared from tea products marketed in the main supermarkets in Poland. It was found that the detected mean levels of organochlorine residues in tea leaves ranged from <LOD to $16.36 \mathrm{ng} \mathrm{g}^{-1}$ dry weight. Among $\mathrm{HCH}$ isomers $\gamma$-HCH in green tea occurred in the highest concentrations. Of DDT metabolites the highest level of pp'DDT (1.96 $\mathrm{ng} \mathrm{g}^{-1} \mathrm{dw}$ ) was in green tea samples. The transfer of OCPs from tea leaves to brew was investigated. The present study revealed that during the infusion process, a significant percentage of the residues, particularly pesticides with high water solubility, were transferred to the infusions. The obtained results show that the percent transfer of each pesticides from tea to the tea infusions ranged from $6.74 \%$ (heptachlor) to $86.6 \%$ (endrin). The detected residues were below the current maximum residue limits (MRLs) for the pesticides.
\end{abstract}

Keywords: Organochlorine pesticides residues (OCPs); Tea leaves; Tea infusion 


\section{Introduction}

Tea is the most popular and widely consumed beverage in the world after water because of its benefits to health, such as antioxidant capacity, weight management, cognitive performance, mental relaxation, and neuroprotection (Pinto 2013). Active components of tea such as tea polyphenols, tea polysaccharide, theanine, and caffeine, are consumed by humans by tea brewing. However, tea farming is affected by a great variety of diseases, weeds and pests. Thus, pesticides (insecticides/fungicides) are used to reduce the severity of infestation (Paramasivam et al 2012; Chen et al 2014). During brewing, pesticide residues in tea leaves are transferred into the infusion and consumed by human (Abd El-Aty et al 2014). Thus, it is not surprising that possible health risks caused by drinking of tea have received a lot of attention in past decades.

There is a lot of scientific evidence indicating that tea consumption might have health promoting properties especially due to the high content of polyphenols (Pandey and Rizvi 2009). Among these healthy effects might be included e.g. reduction of depression, protection against development of cancers, cardiovascular diseases, diabetes, osteoporosis and neurodegenerative diseases (Pandey and Rizvi 2009; Dufresne and Farnworth 2001; Shen et al 2013). On the other hand, it has also been suggested that certain pollutants in tea leaves may pose a health threat to tea drinkers. Special concern should be focused on the presence of pesticides, particularly organochlorine pesticides (OCPs) that are extensively used to control pests and diseases in plants and animals ( $\mathrm{Ji}$ et al 2007). For example the green tea may be contaminated with toxic substances from the raw material, such as pesticides. Previous studies have found pesticides in green tea samples, such as cypermethrin $(26-325 \mu \mathrm{g} / \mathrm{kg})$ (Cajka et al 2012) and acetamiprid (found in $61.1 \%$ of commercial tea samples) (Chen et al. 2011).

OCPs have a low biodegradability and high persistence in the natural environment and therefore pose a danger to the human health, and their use has been restricted or gradually banned. In order to limit pesticide-related health problems for consumers, international organisations and countries have fixed maximum residual levels (MRLs) in foodstuffs (Kaison 2015; Gurusubramanian 2008). However, it is probable that some countries do not respect these MRLs in tea products or use banned pesticides like DDT and aldrin, either due to economic reasons or to preclude outbreaks of diseases like malaria. Thus, it is necessary to monitor presence of pesticides in commercially available tea products in European countries.

Due to the frequent drinking of this beverage, it is utterly crucial that the content of any pesticide residues in tea leaves do not cause risk to the consumer. Therefore, transfer of pesticides from tea leaves into water infusion has been widely studied. It has been observed by several studies that oil content in tea leaves, water solubility (Ws), partition coefficient $\left(\mathrm{K}_{\mathrm{ow}}\right)$, and also Henry's law constant $(\mathrm{H})$ controls the transfer of pesticides from teal leaves 
into water infusion and further from the infusion to the air above (Paramasivam and Chandrasekaran 2014; Jaggi et al 2001; Ozbey and Uygun 2007; Hou et al 2013; Xue et al 2014). One study investigated that some of the soluble organophosphate pesticides had the highest transfer $(19.78-33.3 \%)$ from leaves into water infusion from all tested pesticides. Transfer of other tested pesticides with low water solubility and high Log $\mathrm{K}_{\mathrm{ow}}$ value was negligible (i.e. they strongly enter tea plant tissues but do not move with the circulating sap), including organochlorine acaricides, dicofol and endosulfan (Jaggi et al 2001).

The results from previous studies have showed that transfer of pesticide residues greatly varied from one another depending on their physical and chemical properties. No doubts that this knowledge is crucial for their further application and determination of MRLs. Also, continued monitoring of pesticides in tea products and prepared tea infusions should be a central issue that ensures safety of tea products in European countries. However, the majority of studies has investigated presence of pesticides in tea products of non-EU countries. Pesticide residues could be transferred from tea into its infusion and their degradation products, and subsequently consumed by humans. Extra extraction conditions may induce more pesticide leaching into the infusion and their degradation products to tea and cause toxic effect to humans.

The main purpose of this manuscript is to examine the content of organochlorine pesticides in tea leaves as well as in water infusion of commonly available tea products in Poland. Today tea is the most popular hot drink in Poland. It is served for all meals during the day and also between meals. Therefore it is very important for consumers to be aware of the possible exposure to pesticides while drinking tea.

\section{Materials and methods}

\section{Chemicals}

The quantification of pesticides $(\alpha \mathrm{HCH}, \gamma \mathrm{HCH}, \beta \mathrm{HCH}$, heptachlor, aldrin, heptachlor epoxide, op'DDE, pp'DDE, dieldrin, op'DDD, endrin, op'DDT, pp'DDD, pp'DDT in tea leaves and in brews), concentration and recovery was carried out by fortified samples (with Custom standard pesticide S-20168, AccuStandard Company, USA) and internal standard (cischlordane100 mL, $80 \mathrm{ng} \mathrm{mL}^{-1}$; N11480-10MG, Supelco, USA).

\section{Sample collection}

Various brands of available green $(n=10)$, herbal $(n=10)$, and black tea $(n=10)$ products were collected from different regions in Poland (a total 30 types of tea were analysed).

\section{Extraction of dried tea samples}

Each type of tea was analyzed in 5 replicates $\left(n_{\text {total }}=150\right)$. Dried tea samples $(5 \mathrm{~g})$ were separately fortified with each pesticide under study at $300 \mathrm{ng} \mathrm{mL}^{-1}(200 \mu \mathrm{g})$ and subsequently 
kept for 20 hours at $5^{\circ} \mathrm{C}$ for complete absorption of the applied pesticides. Later, all fortified tea samples were extracted in a hexane/acetone mixture $(3: 1, \mathrm{v} / \mathrm{v})$ using an ultrasound bath (type IS -7S InterSonic, $35 \mathrm{kHz})(3 \times 30 \mathrm{~mL}$ per 10 minutes each time for each sample), and obtained filtrates were transferred to stoppered conical flasks for their further cleanup.

\section{Infusion process and extraction}

Dried tea samples fortified with each pesticide (as described above) were subjected to the infusion process: $5 \mathrm{~g}$ of tea leaves was immersed in $150 \mathrm{~mL}$ of $90^{\circ} \mathrm{C}$ water and brewed for 5 minutes. Further, the tea infusions were cooled up to $40^{\circ} \mathrm{C}$ and the water extracts were decanted and transferred to the separate funnels. The pesticides were extracted in a hexane/acetone mixture (3:1, v/v; ) each in a funnel $(3 \times 30 \mathrm{~mL})$.

\section{Cleanup}

The organic layers were separated, combined in a second stoppered conical flask and concentrated to $5 \mathrm{~mL}$. Concentrated samples were cleaned up in an $\mathrm{Al}_{2} \mathrm{O}_{3}$ (Aluminum oxide Fluka for chromatography, Sigma-Aldrich GmbH, Switzerland) column previously conditioned with n-hexane (purity for chromatography, Merck), and eluted with a nhexane/dichloromethane mixture $(2: 1, \mathrm{v} / \mathrm{v})$. The purified extracts were concentrated by nitrogen stream to $0.5 \mathrm{~mL}$ and analyzed by GC/MS (HP 5973).

\section{Recovery studies}

The percentage recovery of organochlorine pesticides in the examined samples was determined to establish the efficiency of the extraction method. The recoveries were determined by adding known amounts of OCPs standards $\left(0.125,0.250\right.$ and $\left.0.500 \mathrm{ng} \mathrm{g}^{-1}\right)$ into $5 \mathrm{~g}$ of a pesticide-free tea powder before extraction. Further, these samples were subjected to triplicate extraction and clean-up procedures as described above, and all the recovery assays were replicated three times.). The average recovery of the OCPs are ranged from $79.9 \%$ to $102.8 \%$.

The limit of detection (LOD) for each compound was determined as the concentration in the extract which produced an instrumental response at two different ions to be monitored with a signal to noise ratio of 3:1 for the less sensitive signal (Commission Directive 2002/63/EC).

A method blank was included for every ten samples. The LODs were $0.01 \mathrm{ng} \mathrm{g}^{-1}$ on average. The LOQ of OCPs were as follows: pp'DDE (0.06 ng g $\left.{ }^{-1}\right)$, pp'DDE (0.05 $\left.\mathrm{ng} \mathrm{g}^{-1}\right)$, pp'DDT $\left(0.01 \mathrm{ng} \mathrm{g}^{-1}\right), \alpha-, \beta-, \gamma \mathrm{HCH}\left(0.04 \mathrm{ng} \mathrm{g}^{-1}\right)$.

\section{Chromatographic analysis}

Residual content of organochlorine pesticides in previously extracted and purified samples was analyzed by a gas chromatography equipped with a mass spectrometry (GC/MS).

Analyses were performed in triplicate, using the following GC/MS setting: carrier gas-helium; pressure: $0.061 \mathrm{Mpa}$ (8.9 psi); flowrate: $0.8 \mathrm{~mL} \mathrm{~min}^{-1}$, column [HP-5MS/60.0 m; ID $250 \mu \mathrm{m}$, 
$2.25 \mu \mathrm{m}$ film thickness of the active phase] oven temperature: start from $90^{\circ} \mathrm{C}(0.5 \mathrm{~min})$, increase $7^{\circ} \mathrm{C} \min ^{-1}, 220^{\circ} \mathrm{C}(12 \mathrm{~min})$, increase $6^{\circ} \mathrm{C} \mathrm{min}^{-1}, 285^{\circ} \mathrm{C}(7 \mathrm{~min})$, increase $5^{\circ} \mathrm{C} \mathrm{min}^{-1}$, $295^{\circ} \mathrm{C}$ (6min) (post-run). The time of analysis for one sample was $54.9 \mathrm{~min}$.

Targeted compounds were identified and quantified by comparing the mass spectra and retention times of the peaks found in the reference solution with the actual samples.

\section{Statistical analysis}

Statistical analysis (Statistica 10.0) included the determining of significance differences by Tukey's test and Pearson's correlation.

\section{Results}

\section{Residual organochlorine pesticides in tea leaves}

The samples of green, herbal and black tea leaves as well as the infusions prepared from these leaves were examined for residual organochlorine pesticides. Figures (1-4) illustrate the mean concentrations of the 14 OCPs investigated in tea leaves.

$\gamma \mathrm{HCH}$ and $\beta \mathrm{HCH}$ isomers were detected in all tea leaves (Fig. 1). It can be seen that whereas green tea leaves contained the highest concentrations of $\gamma \mathrm{HCH}\left(16.37 \pm 10.53 \mathrm{ng} \mathrm{g}^{-1}\right.$ dry wt.), concentrations of this compound in herbal $\left(6.27 \pm 3.61 \mathrm{ng} \mathrm{g}^{-1}\right.$ dry wt.) and black tea leaves $\left(3.68 \pm 1.89 \mathrm{ng} \mathrm{g}^{-1}\right.$ dry wt.) were significantly $(\mathrm{p}<0.05)$ lower. For $\beta \mathrm{HCH}$, similar values in black and green tea leaves were observed but herbal tea leaves contained the lowest $\beta \mathrm{HCH}$ concentration $\left(1.89 \pm 3.49 \mathrm{ng} \mathrm{g}^{-1}\right.$ dry wt.). Interestingly, the concentrations of $\alpha \mathrm{HCH}$ were below the detection limits in all three tea samples (Fig. 1).

\section{Figure 1}

Other pesticides detected in all tea leaves were heptachlor and heptachlor epoxide (Figure 2). Detected concentrations of heptachlor were considerably higher than concentrations of heptachlor epoxide in all examined leaves.. The lowest concentration of heptachlor $\left(0.828 \pm 1.041 \mathrm{ng} \mathrm{g}^{-1}\right.$ dry wt.) was observed in herbal tea $\left(2.21 \pm 4.47 \mathrm{ng} \mathrm{g}^{-1}\right.$ dry wt. $)$ and the highest in black tea leaves $\left(2.21 \pm 4.47 \mathrm{ng} \mathrm{g}^{-1}\right.$ dry wt.). The concentrations of heptachlor epoxide ranged from $0.331 \pm 0.118 \mathrm{ng} \mathrm{g}^{-1}$ dry wt. (herbal tea) to $0.813 \pm 0.979 \mathrm{ng} \mathrm{g}^{-1}$ dry wt. in green tea leaves (Fig. 2).

\section{Figure 2}

Results from tracking the diene pesticides (aldrin, dieldrin and endrin) in teas leaves are shown in Fig. 3. Whereas dieldrin was found in all the tested tea samples with a significantly higher $(\mathrm{p}<0.05)$ concentration in the green tea $\left(4.46 \pm 3.81 \mathrm{ng} \mathrm{g}^{-1}\right.$ dry wt. $)$ than in the black and herbal teas. Concentrations of aldrin were generally lower and did not differ considerably in any of the teas examined. Furthermore, the samples of green and herbal teas did not contain 
endrin $(<\mathrm{LOD})$ and only a low concentration was found in black tea $\left(0.158 \pm 0.118 \mathrm{ng} \mathrm{g}^{-1}\right.$ dry wt.) (Figure 3).

\section{Figure 3}

The residues of op'DDE and pp'DDE did not differ significantly in any kind of tea.

A low level of pp'DDD was detected in green tea $\left(0.218 \pm 0.596 \mathrm{ng} \mathrm{g}^{-1}\right.$ dry wt.) and it was below the detection limit in black and herbal tea samples. The metabolite op'DDT was below the detection limit for black tea, with the most residues in the green tea $\left(2.09 \pm 0.95 \mathrm{ng} \mathrm{g}^{-1}\right.$ dry wt.). Taking into consideration pp'DDT the lowest levels $\left(0.618 \pm 0.706 \mathrm{ng} \mathrm{g}^{-1}\right.$ dry wt.) were found in the herbal tea leaves, whereas the green tea leaves contained the highest level of this compound (1.96 $\pm 1.56 \mathrm{ng} \mathrm{g}^{-1}$ dry wt.) (Figure 4).

\section{Figure 4}

Tukey's test showed significant differences $(\mathrm{p}<0.05)$ between the green teas, however, for herbal and black teas significant differences occurred only in the case of the following compounds: $\gamma \mathrm{HCH}$, dieldrin, op'DDT and pp'DDT. Taking into account the analyzed pesticides, the following correlations were found: $\gamma \mathrm{HCH} / \mathrm{ppDDT}(\mathrm{r}=0.64), \beta \mathrm{HCH} / \mathrm{dieldrin}$ (0.59), aldrin/pp'DDE (0.54), pp'DDE/pp'DDT (0.67) and op'DDT/dieldrin (0.57).

\section{Transfer of residual organochlorine pesticides from tea leaves to infusion}

The higher dissipation of the pesticide residues occurred in the first $5 \mathrm{~min}$ of the infusion process. In previous studies, it has also been found that the highest rate of penetration of pesticides to the brew took place in first $5 \mathrm{~min}$. This infusion time is recommended on packaging by manufacturers.

The results of the transfer of organochlorine pesticides from tea leaves to the brew are shown in Figure 5.

\section{Figure 5}

\section{Green tea}

It was observed that translocation from tea leaves to infusions was the highest $(75.3 \%)$ and (74.2\%) for dieldrin and $\beta \mathrm{HCH}$ respectively whereas the transfer rates of op'DDE $(29.2 \%)$, pp'DDT (26.0\%), $\alpha \mathrm{HCH}$ (20.5\%), op'DDT (19.8\%), aldrin (17.9\%), heptachlor epoxide (17.9\%), and op'DDD (16.6\%) were comparatively lower (Figure 5). Concentrations of endrin and pp'DDD in infusions were almost negligible or below the detection limits.

\section{Black tea}

Figure 5 shows also the transfer of organochlorine pesticides from black tea leaves to broth. The results showed that the translocation to the black tea infusion ranged from $6.74 \%$ (heptachlor) to $86.6 \%$ (endrin). The transfer of $\alpha \mathrm{HCH}(54.0 \%), \beta-\mathrm{HCH}(41.3 \%)$, and pp'DDE (40.5\%) was lower but still relatively significant, whereas the transfer rates of op'DDE (20.4\%), heptachlor epoxide (17.4\%), dieldrin (17.3\%), aldrin (16.4\%), pp'DDT 
(15.6\%), op'DDT (11.0\%), and heptachlor (6.7\%) were low compare to the rest of the tracked compounds. Transfers to infusion were not taken into account if the pesticide contents were below detection limits.

\section{Herbal tea}

Generally, the transfer of organochlorine pesticides from herbal tea leaves to broth was lower compared to the transfers of both black and green teas (Figure 5). Moreover, pp'DDE, op'DDT, and endrin translocation to the tea infusions were highest $(58.0 \%),(52.5 \%)$ and (44.0\%), respectively, but heptachlor (6.74\%) was much lower. (Table 1$)$.

\section{Table 1}

\section{Discussion}

Pesticides usually decline in concentration on tea bushes as a result of natural factors, including rainfall, dew, volatilisation, air flow, photolysis, biodegradation, moisture, $\mathrm{pH}$ and growth dilution (Murleedharan 1994; Bisen and Hajara 2000).

Tea brew could be a possible source of contamination for humans. Actual exposure depends on the quantity of the residues leached into the tea brew and not the mere presence of residues in the tea (Kottiappan et al. 2013). The data obtained are in agreement with those reported by Cho et al. (2014) who found that the slightly less water soluble pesticides $(0.001-$ $0.019 \mathrm{mg} \mathrm{L}^{-1}$ ) with very high $\log \mathrm{K}_{\mathrm{ow}}$ factors did not infuse into tea brew from prepared tea. Sharma et al. (2008) reported a transfer rate of 10-30\% for some synthetic pyrethroids in an infusion prepared from tea grown under wet and dry seasons. Gupta and Shanker (2008) reported that the brewing process resulted in residue transfer of imidacloprid from tea to infusion from 37 to $49 \%$. Jaggi et al. (2001) noted the transfer from tea leaves to infusion of organochlorine pesticides from 10 to $30 \%$.

Table 2

To a great extent, the transfer of pesticides to the brew depends on their water solubilities and partition coefficient $\left(\mathrm{K}_{\mathrm{ow}}\right)$ values (Table 2$)$ and the character of the herbs, e.g. their oil content (Nagayama 1996; Petersen and Jensen 1986; Ozbey and Uygun 2007). Hayward et al. (2015) noted that the following pesticides were identified on tea leaves, with concentrations between 1 and 3200 ng/g: pp'DDE, op'DDT, pp'DDT, heptachlor, $\alpha, \beta, \gamma-\mathrm{HCH}$ and also anthraquinone, azoxystrobin, bifenthrin, buprofesin, chlorpyrifos, cyhalothrin, cypermethrin, deltamethrin, endosulfan, fenvalerate, phenylphenol, pyridaben, tebuconazole, tebufenpyrad, and triazophos. pp'DDT was found at much higher concentrations than pp'DDE or op'DDT in 9 of 10 teas contaminated with DDTs. It was concluded that one possible source for the DDT currently found on teas is application of dicofol to tea. 
According to European Union regulations (EU Regulation EC No. 1785/2016), the maximum residue levels of organochlorine pesticides are as shown in Table 3. These MRL values ranged from 0.01 to $0.2 \mathrm{mg} \mathrm{kg}^{-1}$.

Table 3

All residual concentrations of organochlorine pesticides in the present study were below the current maximum residue limits (MRLs) for the pesticides (EU Regulation 2016). Fiedler et al. (2002) found that the levels of DDT and its metabolites in tea leaves were within the safety limit of $0.2 \mathrm{mg} / \mathrm{kg}$.

\section{Conclusion}

The present study revealed that during the infusion process, a significant percentage of the residues, particularly pesticides with high water solubility, were transferred to the infusions. On the basis of the above findings it can be concluded that the occurrence of pesticides in infusions is strongly predictable from their physical-chemical properties, including water solubility and octanol-water partition coefficient.

\section{Acknowledgment}

The authors are grateful to Prof. Dr. Mikolaj Protasowicki, the head of the Toxicology Department at the Faculty of Food Sciences and Fisheries, West Pomeranian University of Technology in Szczecin for his kindness and support.

\section{References}

Abd El-Aty AM, Choi JH, Rahman MM, Kim SW, Tosun A, Shim JH. 2014. Residues and contaminants in tea and tea infusions: a review. Food Addit Contam Part A. 31:1794-1804.

Bisen JS, Hajara NG. 2000. Persistence and degradation of some insecticides in Darjeeling tea. J Plant Crop. 28:123-131.

Cajka T, Sandy C, Bachanova V, Drabova L, Kalachova K, Pulkrabova J, Hajslova J. 2012. Streamlining sample preparation and gas chromatography tandem mass spectrometry analysis of multiple pesticide residues in tea. Anal Chim Acta. 743:51-60.

Chen G, Cao P, Liu R. 2011. A multi-residue method for fast determination of pesticides in tea by ultra-performance liquid chromatographyelectrospray tandem mass spectrometry combined with modified QuEChERS preparation procedure. Food Chem. 125:1406-1411. 
Chen H, Liu X, Wang C, Wang Q, Jiang Y, Yin P, Zhu L. 2014. Simultaneous determination of thiophanate-methyl and its metabolite carbendazim in tea using isotope dilution ultra performance liquid chromatography-tandem mass spectrometry. J Chromatogr Sci. 52:111571164.

Cho SK, Abd El-Aty AM, Rahman MM, Choi JH, Shim JH. 2014. Simultaneous multi-determination and transfer of eight pesticide residues from green tea leaves to infusion using gas chromatography. Food Chem. 165:532-539.

Dufresne CJ, Farnworth ER. 2001. A review of latest research findings on the health promotion properties of tea. J Nutr Biochem. 12:404-421.

EU Pesticides Database. 2016. Regulation EC No 1785/2016.

Gupta M, Shanker A. 2008. Persistence of acetamiprid in tea and its transfer from made tea to infusion. Food Chem. 111:805-810.

Gurusubramanian G, Rahman A, Sarmah M, Roy S, Bora S. 2008. Pesticide usage pattern in tea ecosystem, their retrospects and alternative measures. J Environ Biol. 29:813-826.

Hayward DG, Wong JW, Park HY. 2015. Determinations for Pesticides on Black, Green, Oolong, and White Teas by Gas Chromatography Triple-Quadrupole Mass Spectrometry. J Agric Food Chem. 63:8116-8124.

Hou RY, Hu JF, Qian XS, Su T, Wang XH, Zhao XX, Wan XC. 2013. Comparison of the dissipation behaviour of three neonicotinoid insecticides in tea. Food Addit Contam Part A. 30:1761-1769.

Jaggi S, Sood C, Kumar V, Ravindranath SD, Shanker A. 2001. Leaching of pesticides in tea brew. J Agric Food Chem. 49:5479-5483.

Ji J, Deng C, Zhang H, Wu Y, Zhang X. 2007. Microwave assisted steam distillation for the determination of organochlorine pesticides and pyrethroids in Chinese teas. Talanta.71:1068-1074.

Kaison C. 2015. Implications of Maximum ResidueLevels (MRLs) on tea trade. Food and Agriculture Organization of The United Nations. Rome.

Kottiappan M, Dhanakodi K, Annamalai S, Anandhan SV. 2013. Monitoring of pesticide residues in South Indian tea. Environ Monit Assess. 185:6413-6417. 
Murleedharan N. 1994. Pesticide residues in tea: problems and perspectives. Planters Chron. 9:371-375

Nagayama T. 1996. Behavior of residual organophosphorus pesticides in foodstuffs during leaching and cooking. $\mathrm{J}$ Agric Food Chem. 44:2388-2393.

Ozbey A, Uygun U. 2007 Behavior of some organophosphorus pesticide residues in peppermint tea during the infusion. Food Chem. 104:237-241.

Palma DCA, Lourencetti C, Uecker ME, Mello PRB, Pignati WA, Dores EFGC. 2014. Simultaneous determination of different classes of pesticides in breast milk by Solid-Phase Dispersion and GC/ECD. J Braz Chem Soc. 25:1419-1430.

Pandey KB, Rizvi SI. 2009. Plant polyphenols as dietary antioxidants in human health and disease. Oxid Med Cell Longev. 2:270-278.

Paramasivam M, Chandrasekaran S. 2014. Persistence behaviour of deltamethrin on tea and its transfer from processed tea to infusion. Chemosphere. 111:291-295.

Paramasivam M, Kavitha J, Chandrasekaran S. 2012. Persistence behaviour of thiacloprid residues in/on green tea leaves, processed tea and tea infusion. Bull Environ Contam Toxicol. 89:602-605.

Petersen JH, Jensen KG. 1986. Pesticide residues in black tea. Z Lebensm Unters Forsch. 182:489-491.

Pinto MDS. 2013. Tea. A new perspective on health benefits. Food Res Int. 53:558567.

Rissato SR, Galhiane MS, Fernandes JR, Gerenutti M, Gomes HM, Ribeiro R, de Almeida MV.2015. Evaluation of Ricinus communis L. for the phytoremediation of polluted soil with organochlorine pesticides, Biomed Res Int. 1-8.

Sharma A, Gupta M, Shanker A. 2008. Fenvalerate residue level and dissipation in tea and in its infusion. Food Add Contam Part A. 25:97-104.

Shen CL, Chyu MC, Wang JS. 2013. Tea and bone health: steps forward in translational nutrition. Am J Clin Nutr. 98:1694S1699S.

Xue J, Li H, Liu F, Xue J, Chen X, Zhan J. 2014. Transfer of difenoconazole and azoxystrobin residues from chrysanthemum flower tea to its infusion. Food Addit Contam Part A. 31:666-675. 
Zhang X, Mobley N, Zhang J, Zheng X, Lu L, Ragin O, Smith CJ. 2010. Analysis of agricultural residues on tea using d-SPE sample preparation with GC-NCI-MS and UHPLC-MS/MS. J Agric Food Chem. 58:11553-11560. 


\section{List of tables}

Table 1. Percent transfer of organochlorine pesticide residues to the tea brew

Table 2. Water solubility and calculated $\mathrm{K}_{\mathrm{ow}}$ values of organochlorine pesticides under study (Palma et al 2014; Rissato et al 2015)

Table 3. Maximum residue levels $(\mathrm{mg} / \mathrm{kg}$ ) of organochlorine pesticide in tea (EU Regulation EC No. 1785/2016).

\section{List of figures}

Figure 1.The mean $\pm \mathrm{SD}$ concentrations of $\alpha \mathrm{HCH}, \gamma \mathrm{HCH}$ and $\beta \mathrm{HCH}$ in tea leaves Figure 2.The mean $\pm \mathrm{SD}$ concentrations of heptachlor and heptachlor epoxide in tea leaves Figure 3. The mean \pm SD concentrations of aldrin, dieldrin and endrin in tea leaves Figure 4.The mean \pm SD concentrations of DDT and its metabolites in tea leaves Figure 5. Percentage transfer of OCPs compounds to the tea broth 
Table 1. Percent transfer of organochlorine pesticide residues to the tea brew

\begin{tabular}{|c|c|c|c|c|c|c|}
\hline Pesticides & $\begin{array}{l}\text { Concentration in } \\
\text { herbal tea leaves } \\
\text { (ng g-1) }\end{array}$ & $\begin{array}{l}\% \\
\text { transfer } \\
\text { to } \\
\text { infusion }\end{array}$ & $\begin{array}{l}\text { Concentration } \\
\text { in black tea } \\
\text { leaves } \\
\text { (ng g-1) }\end{array}$ & $\begin{array}{l}\% \\
\text { transfer } \\
\text { to } \\
\text { infusion }\end{array}$ & $\begin{array}{l}\text { Concentration in } \\
\text { green tea leaves } \\
\text { (ng g-1) }\end{array}$ & $\begin{array}{l}\% \\
\text { transfer } \\
\text { to } \\
\text { infusion }\end{array}$ \\
\hline$\alpha \mathrm{HCH}$ & $0.000 \pm 0.000^{\mathrm{bc}}$ & 0 & $0.000 \pm 0.000$ & 0 & $0.000 \pm 0.000$ & 0 \\
\hline$\gamma \mathrm{HCH}$ & $6.27 \pm 3.61^{\mathrm{a}}$ & 31.19 & $3.68 \pm 1.89$ & 61.6 & $16.37 \pm 10.52$ & 71.87 \\
\hline$\beta \mathrm{HCH}$ & $1.89 \pm 1.61$ & 20.93 & $5.52 \pm 4.19$ & 41.3 & $4.09 \pm 2.54$ & 74.17 \\
\hline heptachlor & $0.828 \pm 0.49$ & 6.74 & $2.21 \pm 1.47$ & 6.74 & $1.81 \pm 1.26$ & 55.70 \\
\hline $\begin{array}{l}\text { aldrin } \\
\text { heptachlor }\end{array}$ & $2.11 \pm 1.14$ & 8.29 & $2.29 \pm 1.28$ & 16.35 & $2.07 \pm 0.93$ & \\
\hline epoxide & $0.331 \pm 0.118$ & 8.79 & $0.576 \pm 0.276$ & 17.34 & $0.813 \pm 0.979$ & 17.85 \\
\hline op'DDE & $1.52 \pm 1.01$ & 11.85 & $1.106 \pm 1.081$ & 20.34 & $1,210 \pm 0.864$ & 29.16 \\
\hline pp'DDE & $0.718 \pm 0.487$ & 57.96 & $0.746 \pm 0.362$ & 40.46 & $0.797 \pm 0.458$ & 69.31 \\
\hline dieldrin & $1.16 \pm 1.09$ & 8.76 & $1.36 \pm 1.34$ & 17.29 & $4.46 \pm 3.81$ & 75.28 \\
\hline op'DDD & $0.241 \pm 0.180$ & 43.97 & $0.736 \pm 0.418$ & 0 & $0.366 \pm 0.562$ & 16.63 \\
\hline endrin & $0.000 \pm 0.000$ & 0 & $0.158 \pm 0.118$ & 86.60 & $0.000 \pm 0.000$ & 0 \\
\hline op'DDT & $0.778 \pm 0.760$ & 52.53 & 0.0000 .000 & 0 & $2.09 \pm 0.95$ & 19.83 \\
\hline pp'DDD & $0.000 \pm 0.000$ & 0 & $0.000 \pm 0.000$ & 0 & $0.218 \pm 0.596$ & 0 \\
\hline pp'DDT & $0.618 \pm 0.706$ & 7.92 & $0.665 \pm 0.335$ & 15.62 & $1.96 \pm 1.57$ & 25.99 \\
\hline
\end{tabular}


Table 2. Water solubility and calculated $\mathrm{K}_{\mathrm{ow}}$ values of organochlorine pesticides under study (Palma et al 2014; Rissato et al 2015)

\begin{tabular}{|c|c|c|}
\hline Pesticides & Ws $\left(\right.$ Solubility $\left._{2} \mathrm{O}\right) /\left(\mathrm{mg} \mathrm{L}^{-1}\right)$ & $\log \mathrm{K}_{\mathrm{ow}}(\mathrm{pH} 7)$ \\
\hline$\alpha \mathrm{HCH}$ & $2.0(10)$ & $3.82(3.8)$ \\
\hline$\beta \mathrm{HCH}$ & 5 & 3.78 \\
\hline үНCH & $8.52(7.3)$ & $3.50(3.61-3.72)$ \\
\hline heptachlor & 0.056 & 6.1 \\
\hline heptachlor epoxide & 0.0275 & 5.4 \\
\hline aldrin & $0.027(0.011)$ & $6.5(6.5)$ \\
\hline dieldrin & 0.110 & 6.2 \\
\hline endrin & 0.2 & 5.6 \\
\hline op'DDE & 0.14 & 6 \\
\hline pp'DDE & 0.12 & 6.51 \\
\hline op'DDD & 0.1 & 5.87 \\
\hline op'DDT & 0.085 & 6.79 \\
\hline pp'DDD & 0.090 & 6.02 \\
\hline pp'DDT & $0.006(0.025)$ & $6.91(6$ \\
\hline
\end{tabular}


Table 3. Maximum residue levels (mg/kg) of organochlorine pesticide in tea (EU Regulation EC No. 1785/2016).

\begin{tabular}{lcc}
\hline Pesticides & Commodity & Tolerance, $\mathrm{mg} / \mathrm{kg}$ \\
\hline Aldrin & Tea & 0.02 \\
dieldrin & Tea & 0.02 \\
DDT (sum of pp'DDT, op'DDT, & Tea & 0.2 \\
pp'DDE, pp'TDE (DDD) & Tea & 0.01 \\
endrin & Tea & 0.02 \\
heptachlor (sum of heptachlor and & & \\
$\begin{array}{l}\text { heptachlor epoxide } \\
\text { hexachlorocyclohexane (HCH), sum } \\
\text { of isomers, except the gamma isomer }\end{array}$ & Tea & 0.02 \\
\hline
\end{tabular}




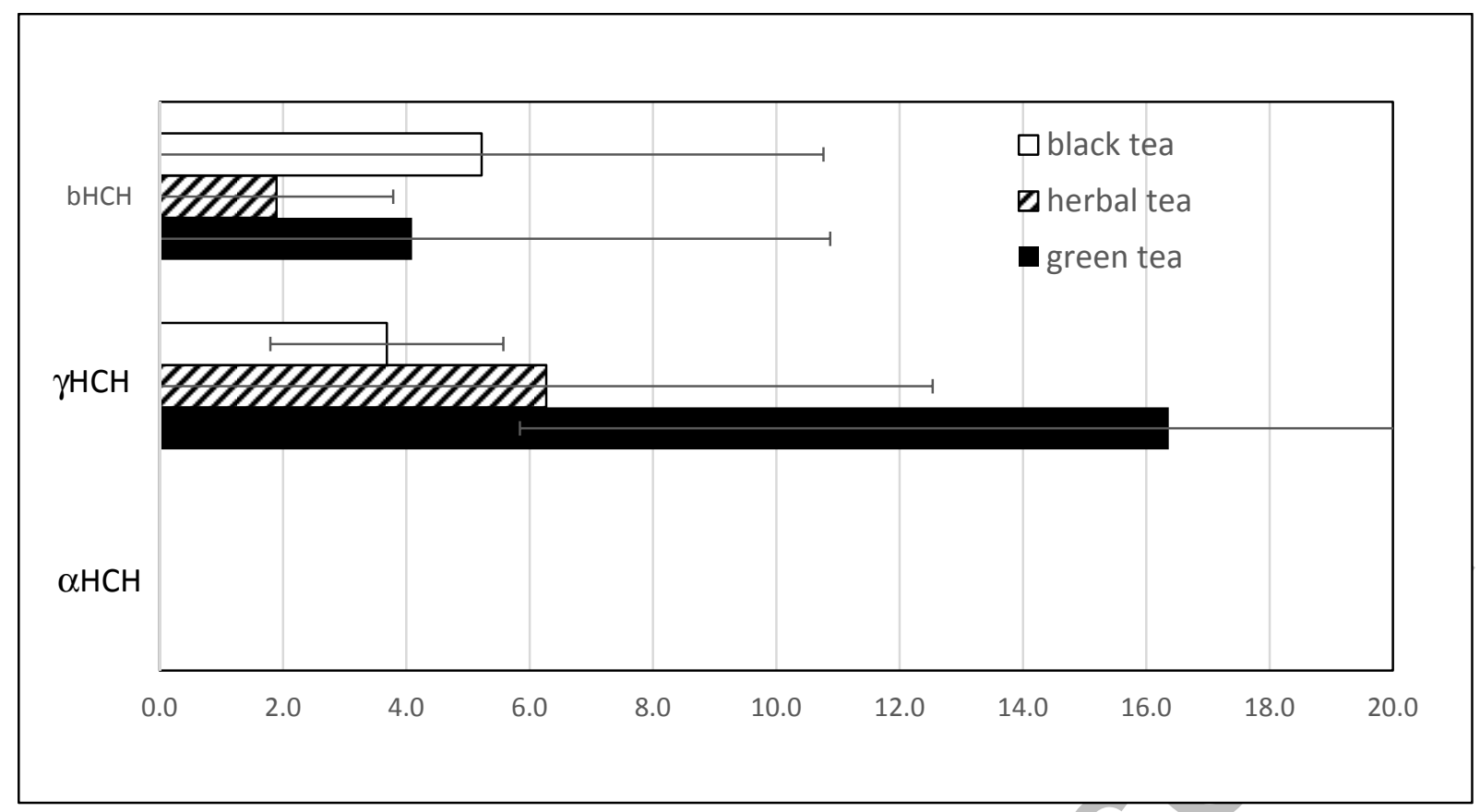

Figure 1.

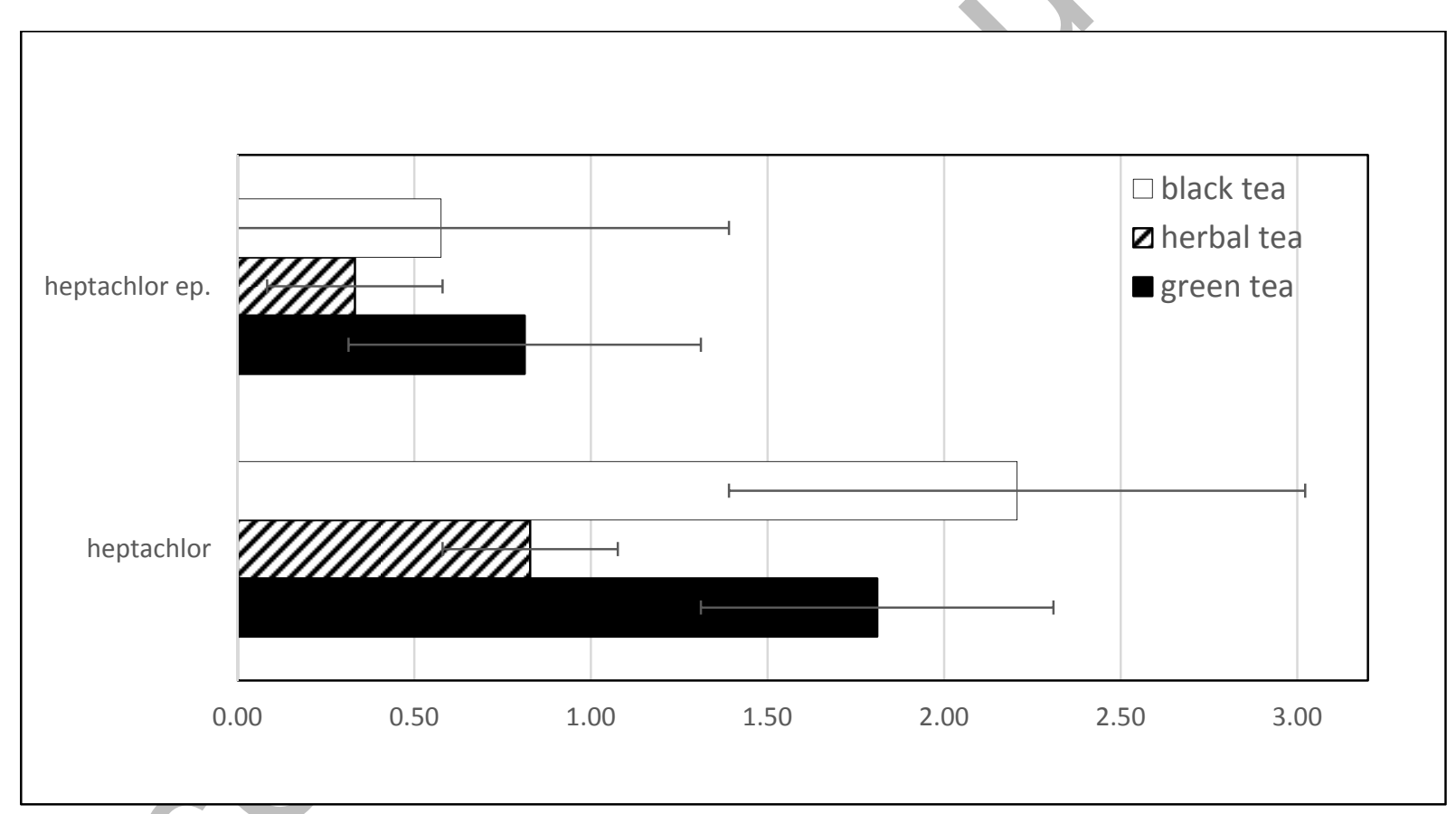

Figure 2. 


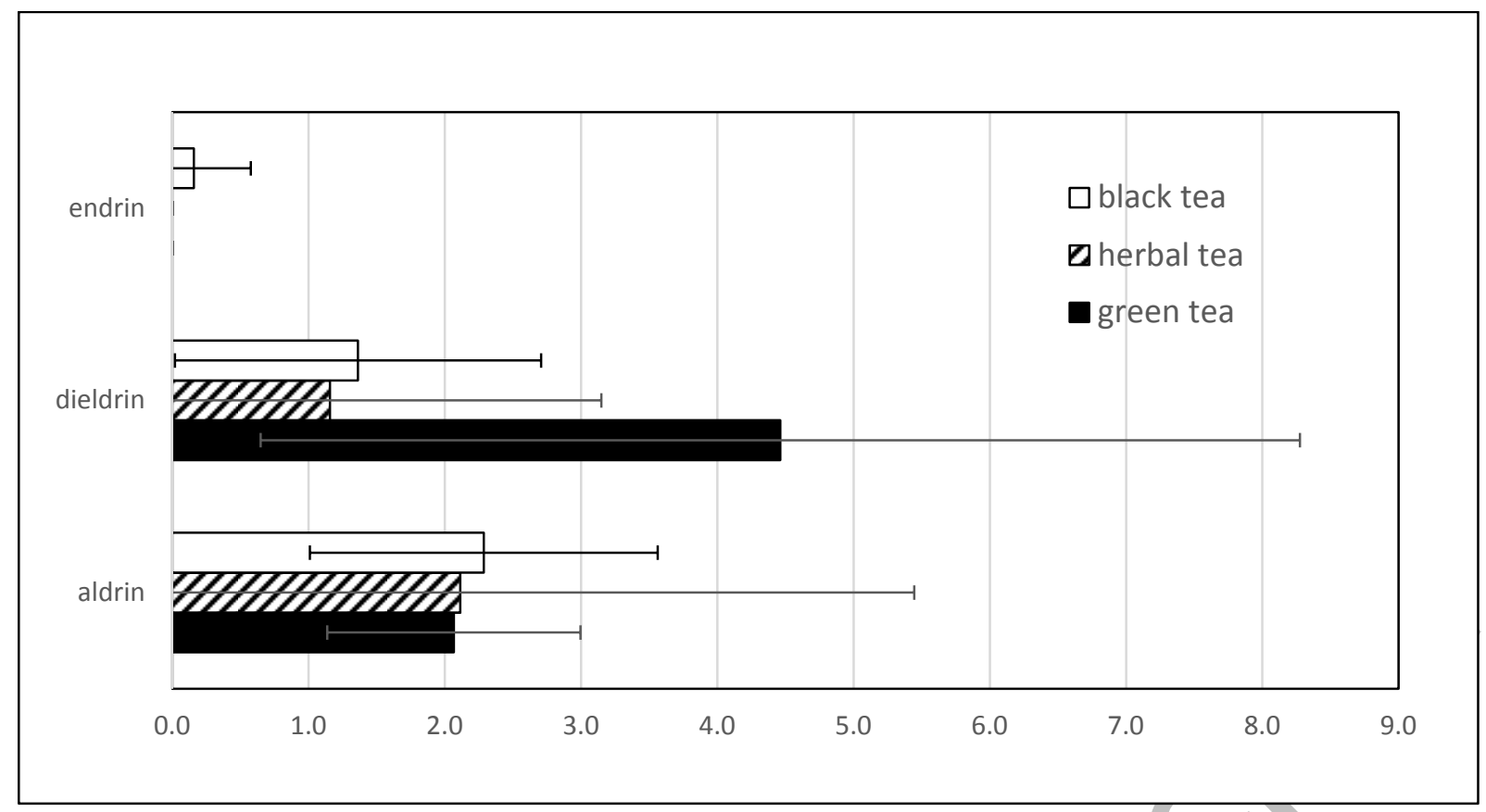

Figure 3.

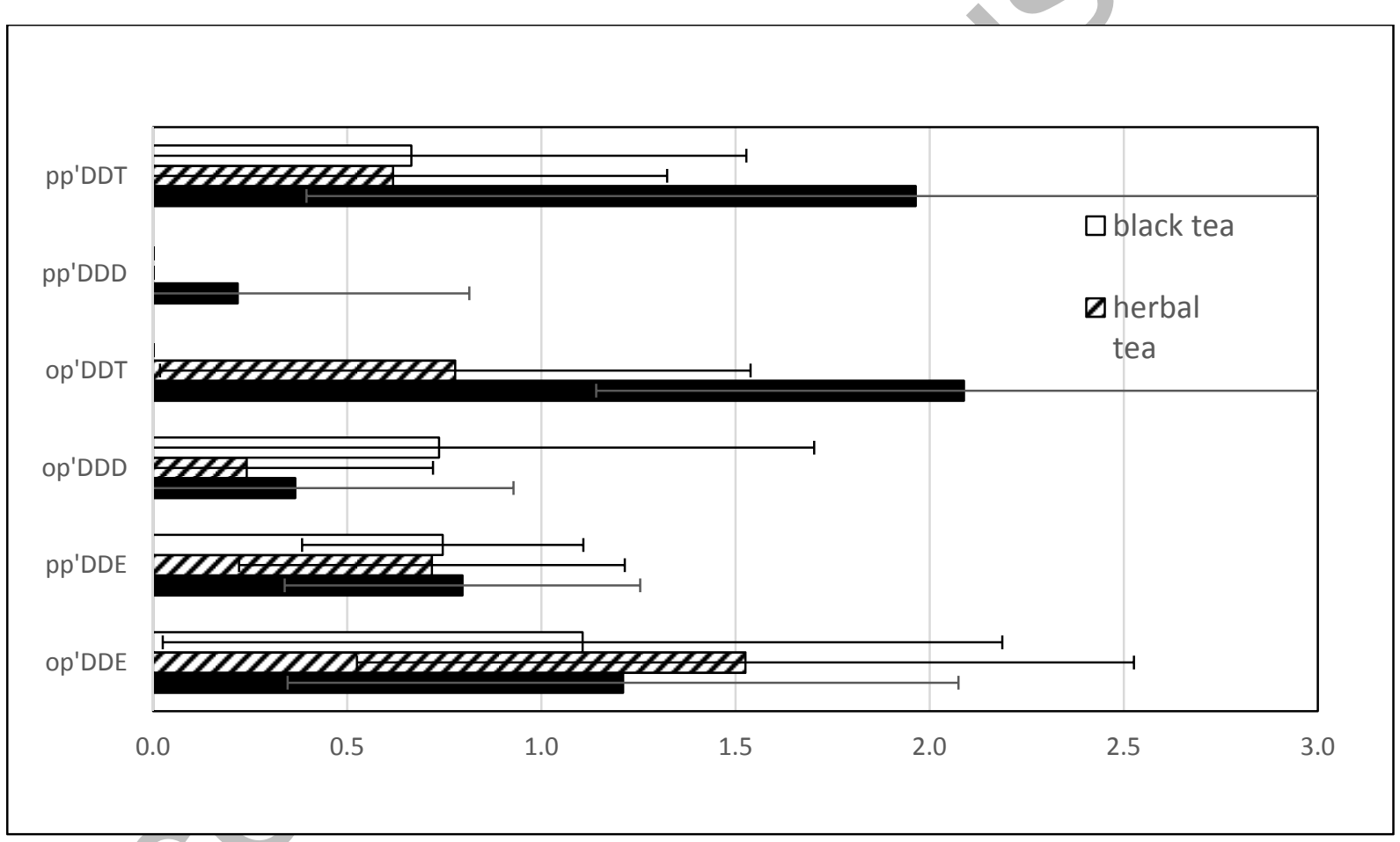

Figure 4. 


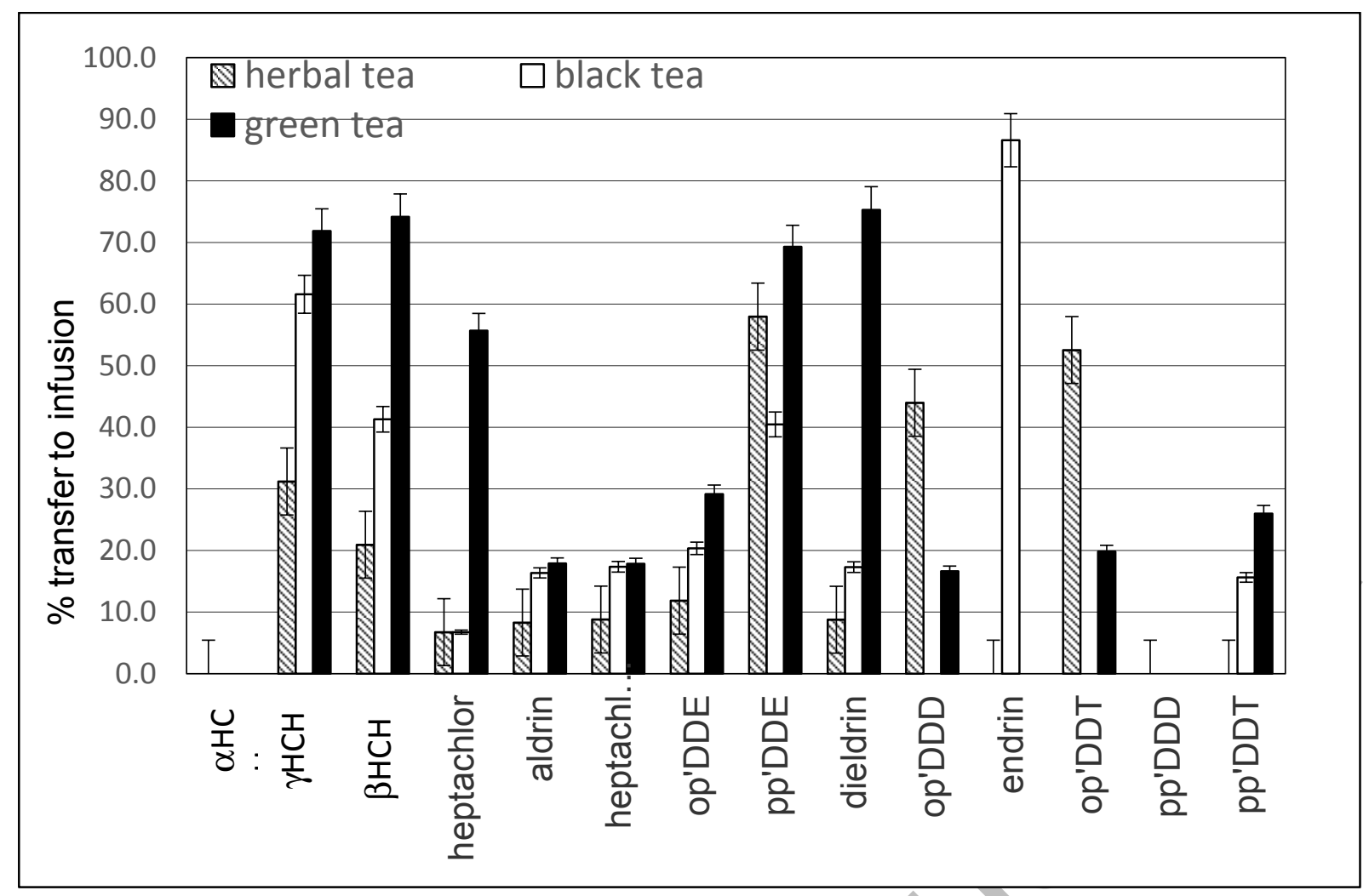

Figure 5. 